\title{
Using Third-Party Inspectors in Building Energy Codes Enforcement in India
}

S Yu

M Evans

P Kumar*

L Van Wie*

V Bhatt**

* Alliance to Save Energy

** Brookhaven National Laboratory

January 2013

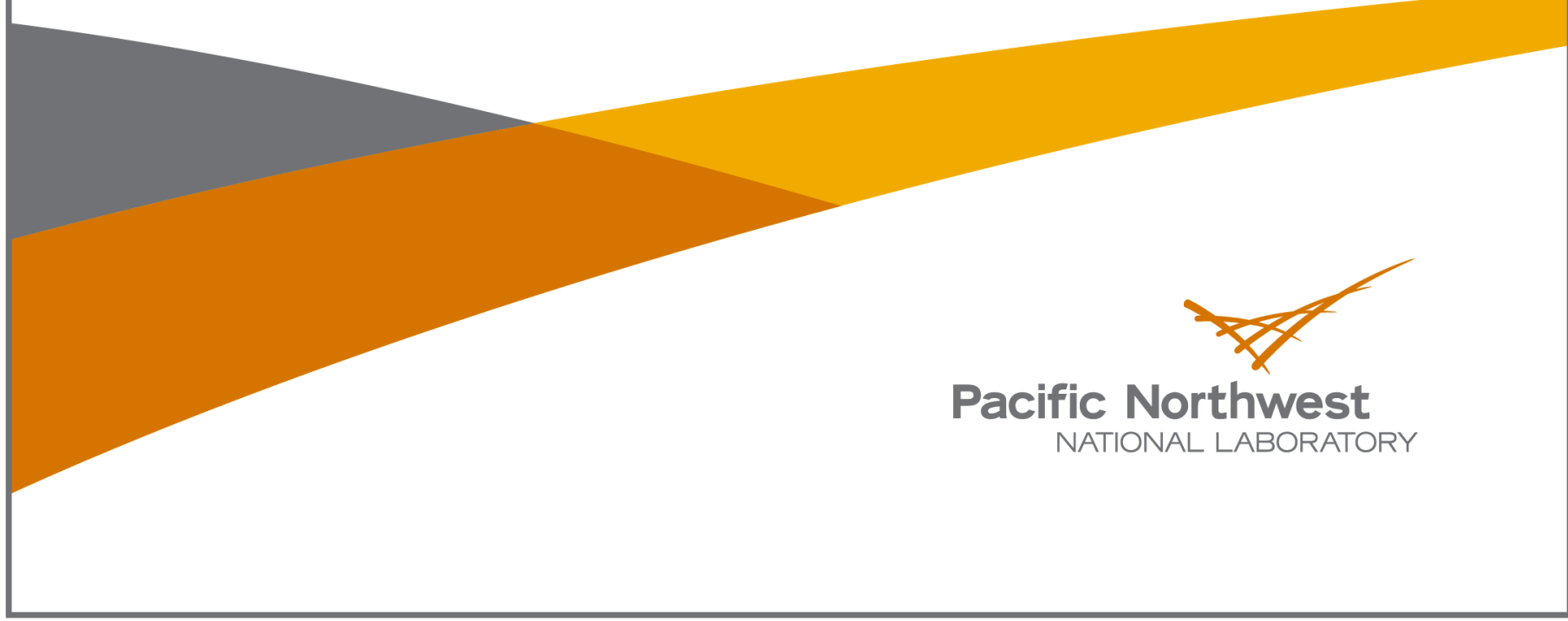




\title{
DISCLAIMER
}

This report was prepared as an account of work sponsored by an agency of the United States Government. Neither the United States Government nor any agency thereof, nor Battelle Memorial Institute, nor any of their employees, makes any warranty, express or implied, or assumes any legal liability or responsibility for the accuracy, completeness, or usefulness of any information, apparatus, product, or process disclosed, or represents that its use would not infringe privately owned rights. Reference herein to any specific commercial product, process, or service by trade name, trademark, manufacturer, or otherwise does not necessarily constitute or imply its endorsement, recommendation, or favoring by the United States Government or any agency thereof, or Battelle Memorial Institute. The views and opinions of authors expressed herein do not necessarily state or reflect those of the United States Government or any agency thereof.

\author{
PACIFIC NORTHWEST NATIONAL LABORATORY \\ operated by \\ BATTELLE \\ for the \\ UNITED STATES DEPARTMENT OF ENERGY \\ under Contract DE-AC05-76RL01830 \\ Printed in the United States of America \\ Available to DOE and DOE contractors from the \\ Office of Scientific and Technical Information, \\ P.O. Box 62, Oak Ridge, TN 37831-0062; \\ ph: (865) 576-8401 \\ fax: (865) 576-5728 \\ email: reports@adonis.osti.gov

\footnotetext{
Available to the public from the National Technical Information Service, U.S. Department of Commerce, 5285 Port Royal Rd., Springfield, VA 22161 ph: (800) 553-6847 fax: (703) 605-6900 email: orders@ntis.fedworld.gov online ordering: http://www.ntis.gov/ordering.htm
} 


\title{
Using Third-Party Inspectors in Building Energy Codes Enforcement in India
}

\author{
S Yu \\ M Evans \\ P Kumar* \\ L Van Wie* \\ V Bhatt** \\ * Alliance to Save Energy \\ ** Brookhaven National Laboratory
}

January 2013

Prepared for the U.S. Department of Energy

under Contract DE-AC05-76RL01830

Pacific Northwest National Laboratory

Richland, Washington 99352 


\title{
Using Third-Party Inspectors in Building Energy Codes Enforcement in India
}

\author{
Sha Yu ${ }^{\mathrm{a}}$, Meredydd Evans ${ }^{\mathrm{a}}$, Pradeep Kumar ${ }^{\mathrm{b}}$, Laura Van Wie McGrory ${ }^{\mathrm{b}}$, Vatsal Bhatt ${ }^{\mathrm{c}}$ \\ ${ }^{a}$ Pacific Northwest National Laboratory; ${ }^{\mathrm{b}}$ Alliance to Save Energy; ${ }^{\mathrm{c}}$ Brookhaven National Laboratory
}

\section{Background}

India is experiencing fast income growth and urbanization, and this leads to unprecedented increases in demand for building energy services and resulting energy consumption. In response to rapid growth in building energy use, the Government of India issued the Energy Conservation Building Code (ECBC) in 2007, which is consistent with and based on the 2001 Energy Conservation Act.

ECBC implementation has been voluntary since its enactment and a few states have started to make progress towards mandatory implementation. Rajasthan is the first state in India to adopt ECBC as a mandatory code. The State adopted ECBC with minor additions on March 28, 2011 through a stakeholder process; it became mandatory in Rajasthan on September 28, 2011. The State of Odisha and the Union Territory of Puducherry also amended ECBC and sent out notifications for mandatory adoption recently. According to the Bureau of Energy Efficiency (BEE), 16 Indian States are now in various stages of ECBC implementation and adoption, and these also include Uttar Pradesh, Karnataka, Uttarakhand, Kerala, Punjab, Gujarat, Haryana, Madhya Pradesh, Andhra Pradesh, Tamil Nadu, Maharashtra, Chhattisgarh, and West Bengal.

Since its inception, India has applied the code on a voluntary basis, but the Government of India is developing a strategy to mandate compliance. It was also expected that during the voluntary period building technology and service providers would be able to develop market for energy-efficiency products and services required in ECBC. Implementing ECBC requires coordination between the Ministry of Power and the Ministry of Urban Development at the national level as well as interdepartmental coordination at the state level. One challenge is that the Urban Local Bodies (ULBs), the enforcement entities of building by-laws, lack capacity to implement ECBC effectively. For example, ULBs in some states might find the building permitting procedures to be too complex; in other cases, lack of awareness and technical knowledge about ECBC slows down the amendment of local building by-laws as well as ECBC implementation.

The intent of this white paper is to share code enforcement approaches with Indian decision-makers. Given the limited capacity and human resources available in the state and local governments, involving third-party inspectors could rapidly expand the capacity for plan reviews and broad implementation. However, the procedures of involving third-parties need to be carefully assessed and designed based on the capacity and capabilities of the municipal officials in order to guarantee a fair process. For example, there should be multiple checks and certification requirements for third-party inspectors, and the government should have the final approval when third-party inspectors are used in a project. This paper discusses different approaches of involving third-parties in ECBC enforcement; the Indian states may choose the approaches that work best in their given circumstances. 


\section{Code Enforcement Approach}

Building energy codes could be enforced by code officials from government agencies, by third-party inspectors, or through a hybrid approach. State and local governments are important to the success of building energy codes implementation. The programs and policies run by the state and local governments influence the effectiveness of codes in India because states have the authority to mandate the codes by incorporating it into the General Development Control Regulations for the State and local governments (i.e., ULBs in India) are responsible for energy code enforcement and incorporating the code into local building by-laws. Most U.S. States enforce energy codes through state or local governments. For example, in the U.S. State of California, building energy code is enforced by local building departments and/or fire districts (CBSC, 2010). Builders are required to submit code compliance documentation to enforcement agencies and these agencies will review compliance information and inspect buildings in order to issue building permits (Sun et al., 2012).

Using third-party inspectors can also help code enforcement and improve code compliance. The extensive use of third-party professionals in inspection and compliance checks has significantly contributed to the rapid growth in compliance with energy codes in China. The Chinese energy codes are enforced at the local level by both governmental and private entities. The private third parties, in fact, play a major role in energy code enforcement. They perform plan reviews and onsite inspections throughout the construction projects, and the government-funded organizations, local Quality Control and Testing Stations and Construction Administration Departments, do only limited compliance checks and heavily rely on the report and documentation provided by third parties. There are multiple checks and balances in the Chinese third-party system. The third-party inspectors are required to take trainings and obtain licenses by passing a national exam. And third parties are at the risk of suspending or losing their license for violations related to building energy codes. In the Chinese approach, the third-parties are hired and paid by building owners or developers, but regulated and monitored by local authorities (Evans et al., 2010; Shui, 2012).

Third-party inspectors could also be used to perform only certain inspections, and the code officials still need to conduct the majority of compliance checks. Compared to the Chinese system that heavily relies on third parties, this is more like a hybrid system. For example, Fairfax County, Virginia, started a Certified (Third Party) Inspections Program for commercial buildings in 2012 (Fairfax County, 2012). Under the program, property owners and construction contractors have the option to hire certified third parties to conduct certain construction inspections (e.g. building shell, insulation, and energy conservation material). This also requires checks and balances as third parties need to be certified by the County's Commercial Inspections Division and are not allowed to have any financial or personal interest in the project (Evans et al., 2009; Fairfax County, 2012). Similarly, the State of Washington has a voluntary program encouraging jurisdictions to use qualified individuals for plan review and inspections; voluntarily using third parties has helped Washington State increase code compliance rates from 55\% to 94\% (Makela et al., 2011).

In the traditional approach, building owners and developers pay the inspection fee to code officials as part of the fees for construction or occupancy permits; using third parties will shift part of this inspection fee from paying to code officials to paying to third parties for plan review and inspection and this will not necessarily increase the cost of construction. In addition, using qualified third-party inspectors to review plans and conduct inspections has several advantages. Training existing inspectors and code officials is 
normally time-consuming, and using third parties can help build enforcement capacity rapidly. In addition, compared to code officials, these third parties have more technical expertise in handling the complexities of technical issues. As an energy code becomes more complex and requires more specialization, using third-party inspectors would help the smooth code implementation. Moreover, local jurisdictions may resist enforcing an energy code because of inadequate resources, and third-party plan review and inspection can also be a good way to help jurisdictions with a lack of resources enforce ECBC and solve the workload problems that ULBs may face. However, there is also a risk of using third parties. If third parties are paid by developers or building owners, they may have financial interests in lightly enforcing the code. Therefore, a well-designed third-party system requires adequate checks and balances. Table 1 compares different code enforcement approaches, highlighting the strengths and weaknesses of each.

Table 1: Comparison of different enforcement approaches

\begin{tabular}{|l|l|l|}
\hline Enforcement & Roles and Responsibilities & Strengths and Weakness \\
\hline Government & $\begin{array}{l}\text { Code officials review plan, inspect construction, } \\
\text { and certify construction and occupancy permits. }\end{array}$ & $\begin{array}{l}\text { Pros: rigorous; easy to enforce; } \\
\text { Cons: overload capacity of code } \\
\text { officials. }\end{array}$ \\
\hline $\begin{array}{l}\text { Third-party } \\
\text { inspectors }\end{array}$ & $\begin{array}{l}\text { Hired by developers, building owners, or the } \\
\text { construction contractor, third-party inspectors } \\
\text { review plan, inspect construction, and prepare } \\
\text { documentation on compliance; code officials } \\
\text { accept documentation and issue the occupancy } \\
\text { permit. Third-party inspectors are the main } \\
\text { entities to conduct plan review and inspection } \\
\text { checks. }\end{array}$ & $\begin{array}{l}\text { Pros: building code enforcement } \\
\text { capacity rapidly; raising market } \\
\text { awareness; reduced permitting time; } \\
\text { Cons: requiring checks and balances; } \\
\text { potential to increase the cost of } \\
\text { construction by asking } \\
\text { developers/contractors to hire third- } \\
\text { parties. }\end{array}$ \\
\hline Both & $\begin{array}{l}\text { Construction contractors have the option of } \\
\text { choosing third-party inspectors to perform certain } \\
\text { inspections or the code officials could choose to } \\
\text { contract part of the inspection work to third } \\
\text { parties; the majority work of plan review, } \\
\text { documentation, and complete inspection are still } \\
\text { performed by code officials. }\end{array}$ & $\begin{array}{l}\text { Pros: reducing the workload of code } \\
\text { officials by distributing the technical } \\
\text { work to accredited third-party } \\
\text { inspectors; } \\
\text { Cons: requiring credentials for third- } \\
\text { party inspectors. }\end{array}$ \\
\hline
\end{tabular}

\section{Key Elements of Third-party Certification Program}

Per the discussion above, in the early stage of code enforcement, local government officials and inspectors may not be well-trained in the energy code enforcement and compliance checks; using thirdparty inspectors specializing in energy code is one of the most effective ways to address the compliance issue. The design of the system is critical to ensuring robust checks and balances, and this will be discussed in detail shortly. There are several financial models for involving third parties. Third-party inspectors could contract directly with permit applicants (e.g. developers and construction contractors) or with the building department. In either case, third parties help improve and strengthen code enforcement that may not otherwise happen due to lack of capacity and local government resources. 
There are many advantages of using third parties. First, with the establishment of a training and certification program, there would be a group of professionals (i.e. third parties) that are knowledgeable and well-trained about building energy codes (NEEP, 2009). Second, using third parties could free code officials from the majority of additional work they take because of building energy codes and ensure that they are not overloaded. Third, if the third parties are directly contracted with building owners or developers, this would simplify the work procedure of ULBs, although the program requires supervision and review from the state or local government. Finally, it may raise market awareness of building energy codes; in the U.S. State of Washington, for example, using third parties was considered by the market as a signal that code compliance would be more stringent, and thus the market was encouraged to improve the compliance rate (Price, 2009; Sun et al., 2012).

Although there are benefits of involving third parties in plan review and inspection, checks and balances and appropriate credentials are required in order to guarantee a fair process (NEEP, 2009). These may include:

- Specification of the qualifications of third parties;

- Specification of the type of documentation required to determine a given project's compliance with the code;

- Determining how a municipality will make its final determination;

- Ensuring there is no conflict of interest on the part of the third party inspector;

- Sanctions for violations such as losing a license or getting fined;

- A system to randomly check the performance of third parties.

The following section will discuss these processes in detail.

\section{Existing infrastructure of third-party inspectors}

It is important to examine if any existing infrastructure could support the third-party program. The Indian Green Building Council currently runs the Leadership in Energy and Environmental Design (LEED) program that promotes green buildings and encourages energy savings in buildings. The LEED program uses accredited professionals (APs) to evaluate the green and energy features of commercial buildings. India's Green Rating for Integrated Habitat Assessment (GRIHA) system uses third-party evaluation for inspection and reporting; third party evaluators are required to attend a three-day Evaluator and Trainers Program and pass the exam. The GRIHA rating also uses energy auditors certified by the National Productivity Council and BEE for the post-occupancy evaluation. Overlap exists between energy code inspections and the work of LEED APs and GRIHA evaluators. Individuals experienced in inspecting these projects will have some experience with energy efficiency inspections. However, a caveat should be considered. These third-party inspectors are not specifically trained on ECBC requirements.

Therefore, none of the experts mentioned above (i.e. LEED APs, GRIHA inspectors, or BEE certified energy auditors) should automatically receive certification without going through the ECBC licensing procedure discussed below.

In addition, design and construction professionals such as architects and engineers who are experienced in design and construction procedures might also be familiar with ECBC. They could be potential candidates for third-party inspectors. 


\section{Qualifications and licensing requirements of third-party inspectors}

There are several models that can be used to establish a licensing or accreditation system to ensure a minimal level of competence of third-party inspectors; the licensing system can be governed by either state or local government, or private organization. Third-party inspectors should have a minimum level of experience to ensure they have an adequate understanding of building energy efficiency, $\mathrm{ECBC}$, and its legal framework. Another minimum qualification is that all inspectors should be licensed architects or engineers or have an undergraduate degree in a construction-related field. This would ensure that the applicants have at least a basic understanding of construction and buildings. Beyond these minimum qualifications, in order to obtain the certificate, third-party inspectors also should be required to complete trainings on ECBC and building science as well as to pass third-party certification exam. There is also a model where it is a company, instead of an individual inspector, that is certified and performs compliance checks. One concern of using this model in India is that local governments may have limited capacity to handle and judge qualifications of small companies that might not be financially stable. The third-party program could also consider certifying both companies and individual inspectors.

Training and certification requirements can vary for inspectors, since compliance checks for different types of buildings require different levels of skills. For example, the Chinese system divides construction inspection companies into three categories: comprehensive (covering all kinds of construction projects), specialized (working on construction projects for a particular sector or subsector), and related services (providing construction management and consulting services). The type of certification is related to the company's registered capital, number of certified construction inspectors, documentation and equipment demonstrating business and technical capacity, and record of performing related activities (Shui, 2012). Table 2 below provides an example of licensing requirements in Washington State, in which obtaining certification depends on both successful completion of an exam and experience in field inspection.

Table 2: Licensing requirements for third-party inspectors for the Washington State Special Plan Examiners Program

\begin{tabular}{|l|l|l|}
\hline Qualification Level & Project/Building Type & Required Qualifications \\
\hline Basic/Category I & Simple & Written exam \\
\hline Category II (Level One) & $\begin{array}{l}\text { Less than three stories; not } \\
\text { involving a professional engineer } \\
\text { or licensed architect }\end{array}$ & $\begin{array}{l}\text { Written exam; recommendation } \\
\text { letters; relevant two-year degree; } \\
\text { hands-on experience }\end{array}$ \\
\hline Category II (Level Two) & $\begin{array}{l}\text { Greater than three stories; } \\
\text { involving a professional engineer } \\
\text { or licensed architect }\end{array}$ & $\begin{array}{l}\text { Written exam; professional } \\
\text { engineer or licensed architect }\end{array}$ \\
\hline
\end{tabular}

Source: NEEP, 2009; Price, 2009.

\section{Training and certification program}

The training program associated with a third-party certification program should be comprehensive and include: developing the training curriculum, determining the amount of training required for each type of certification, and logistical arrangments (NEEP, 2009). Since several states and organizations in India are developing training materials and conducting ECBC training, the existing ECBC training materials could be used for the training of third-party inspectors. However, the current training materials do not include materials and courses on compliance checks; these materials need to be developed and incorporated into the training for third-party inspectors. 
The U.S. Agency for International Development's ECO-III project and BEE have developed ECBC compliance check software -- ECOnirman. ECOnirman was launched in September 2011 and can be used by architects, engineers, code officials, and inspectors to determine whether new commercial buildings or additions meet ECBC requirements. ECOnirman can facilitate and simplify the compliance check process for third-party inspectors and code officials; however, the software needs to be further fine-tuned and improved based on the user feedback and real time requirement. The training for third-party inspectors and code officials should also include the training on ECOnirman.

The implementation of the training program falls to state and local governments or private organizations (e.g. Indian Green Building Council (IGBC), Indian Society of Heating, Refrigerating and AirConditioning Engineers (ISHRAE), trade associations, and universities). BEE or other national agencies can have a role in guiding states in creating the pool of trainers during the initial phase of ECBC implementation. These organizations can use the exisitng ECBC trainers, or train new trainers for the third-party training program. Implementation of the training program also needs to consider the logistics. The governing organizations need to determine the number of training sessions, the length of time for each session, the way to deliver trainings, and the locations. The governing orgnizations should also coordinate and collaborate with other interested parties such as IGBC, municipalities, and ISHRAE. These trainings also apply to building code officials.

Unlike the training program, the certification program needs to be conducted by accredited organizations - either national, state, and local governments or private third-party organizations such as the National Productivity Council, IGBC, or ISHRAE. For example, in China the Ministry of Housing and UrbanRural Development (MOHURD) is reasponable for issuing licenses for third-party professionals; in order to obtain licenses, third parties are required to complete training courses and pass the national licnesing exams. The training, exam, and licensing could also be governed by different organizations. In the U.S. State of Maine, the State Planning Office uses training programs and examination materials developed by the International Code Council, and the State Planning Office developes a process to certify third-party inspectors who have passed the exam and maintain the third-party program (NEEP, 2009). In Washington State, the Washington Association of Building Officals is responsible for administering the exams (e.g. registration and scheduling the exams), while the International Council of Building Officials is responsbile for developing and maintaining the certification exams (NEEP, 2009). It is also feasible that private organizations could administer and maintain the certificate program. The Clean Development Mechanism (CDM) program uses accredited entities to submit requests for project registrations and verifications; a lot of CDM verifiers are private organizations. Similarly, the LEED program is governed by a private entity (i.e. IGBC in India), and IGBC also certifies LEED APs, equivalent to third-party inspectors in the code implementation.

In collobration with local stakeholders, the certification entities also need to determine logistics of the third-party exams. This includes determining the number of test locations, the number of times the exam will be given, a process of administrating the exams (e.g. registration, proctoring, and grading), the process for certifying (and maintaining a list of) individuals who have passed the exam, and the process for renewing the certificates. The certification entities should also govern the renewal of the certificates. The third parties need to be actively working in th field and engaged in continuing learning programs, in order to obtain up-to-date information and gurantee the work quality. If the accredited third-party 
inspector has not worked in the field for some time (for example, two years), he can be required to take the exam and be accredited again before being allowed to practice.

Certification ensures that inspectors have demonstrated a minimum level of knowledge and are qualified. It helps building professionals improve their competency by receiving the credetnials. It also improves market acceptance and penetration by signaling that the code is to be taken seriously and that enforcement is important.

Setting up a third-party inspection program will take some time. In general, developing a third-party system will involve (Yu et al., 2012):

1. Convening a certification exam committee to oversee the development of the examination

2. Developing curriculum and reference materials for the certification exam

3. Performing a job task analysis to determine what knowledge inspectors must have and in which part(s) of the code they will need to become experts

4. Developing a question bank that will be used to develop certification exams; note that certifications for plan review and inspection will be different

5. Developing and administering the exams.

Finally, the third-party certificate program needs to be administered and maintained on an ongoing basis. As ECBC may be updated and revised in the future, the training and certification associated with ECBC inspectors should also be periodically updated (e.g. the third-party certificate in China is valid for five years). Building officials and third party inspectors who want to maintain their certification should update their training and certificates based on the code update schedule.

\section{Checks and balances}

Under a third-party system, code officials, permit applicants, and third-party inspectors share responsibilities for energy code compliance. The success of the third-party program in many U.S. states and China is rooted in the clearly announced code compliance responsibilities, penalties for noncompliance and violation of codes, and rigorous checks and balances of the system.

The Indian State code enforcement agency or ULBs could choose to administer the code in-house, contract with third parties, or leave enforcement to third-party inspectors hired by permit applicants. However, the latter two approaches of involving third-party inspectors require checks and balances of the system to guarantee a fair and objective process. As discussed above, as a minimum requirement, thirdparty inspectors need to be certified by an accredited entity to conduct plan reviews and construction inspections or administer and enforce enegy codes.

Beyond the certification, other mechanisms are also required to avoid a potential conflict of interest. In Fairfax County in the U.S., third parties are not allowed to have any financial or personal interest in the program. The Chinese third-party system involves multiple checks and supervision. The local quality supervision stations conduct scheduled or random inspections during the construction stage to make sure the construction complies with the approved design; MOHURD also conducts annual inspection checks and randomly picks samples from major provinces and cities. The administering agencies can suspend or revoke the licenses of third parties if there are violations related to building energy codes (Evans et al., 2010). In Denmark, third parties, paid by the government, are also used to do random checks, but entities who perform original compliance checks and who do random checks need to be from two different 
jurisdictions far away from each other to avoid potential competition; the government is also involved in some checks. In the U.S. State of Maine, the third party must be an independent inspector not in the employ of the construction firm or the contractor. The Maine law also allows revocation of third-party certificates by the District Court for fraud and deception, incompetence to perform proper duties, or lack of reasonable care or judgment of duties (Maine, 2011). Financial penalties could also be used. In Australia, if violations are found, third parties get fined in proportion to the value of energy wasted.

In the ECBC implementation, licensed architects and/or energy auditors who complete required trainings on ECBC and compliance check could serve as third-party inspectors with a temporary state certificate and be directly hired by developers. ULBs will perform random checks on projects approved by thirdparty inspectors. If a project that has been inspected by a third party is, in fact, not compliant with ECBC, the certificate of the third-party inspector could be revoked, and developers could be fined with fees or an extended project review period, in addition to receiving non-compliance penalties. Of course, this implies that ULBs must also have the capacity to check plans and buildings.

\section{Third-Party Certification in India}

Compliance with the ECBC will be a significant challenge for the construction industry as well as for the agencies that will monitor, supervise and enforce the code, because the implementation of the code requires significant technical, knowledge-based, and market-dependent institutional and administrative measures related to efficient energy consumption in buildings. ECBC Implementation as a whole requires the adoption of design practices and guidelines prescribed in the code at the planning level. Once the code is made mandatory, State government agencies will be responsible for its implementation and enforcement through local municipal authorities, which enforce building by-laws.

As of now BEE has not issued any clear guidelines on the compliance mechanism, noting that states are free to choose the compliance mechanism based on their need and assessment of their requirements. In addition, BEE is considering establishing a third-party certification program for ECBC inspectors. BEE has been considering certification of ECBC Accredited Professionals (similar to the certified energy auditor program of BEE) who can act as a resource pool for ECBC compliance activities. As of now, $\mathrm{BEE}$ has empanelled ECBC architects based on certain qualification criteria. The accreditation process has still not been initiated, but it is expected that it will include training (classroom sessions) followed by an exam. It is also expected that ECBC building design teams will include at least one ECBC Accredited Professional to deal with the requirements.

Several states, developmental agencies and other private companies are also having discussions regarding compliance procedures and mechanisms. Three models that have been discussed are:

1. Empower State Designated Agencies (SDAs) by developing a training framework for them. Each SDA would work as an independent body (not as part of any other organization), and would be held responsible for carrying out all the activities related to ECBC - including compliance in their respective states. However, this will also require experts who can handle the scope of compliance; one option is for the SDAs to contract with BEE-accredited ECBC professionals to assist in the process of compliance. 
2. Appropriate government departments (e.g. Urban Local Bodies) would take responsibility for the final compliance certification, based on independent ECBC certified/expert architects' reports. Under this model, the owner of each building would have to hire the services of locally available ECBC certified experts/ECBC accredited professionals to carry out checks at various levels (e.g., building plan, construction, commissioning) and submit reports to the owner -- either for approval or corrective action. The owner would then submit the reports to the government-appointed agency for review and final approval.

3. Third-party Inspectors act as the major entity for compliance checks. Under this model the thirdparty inspector would be independent of the design and construction team, and also not part of the ULB. The third-party inspector would review the design documents, inspect construction of a building, and submit a report and a recommendation letter to the ULB stating that the building meets the applicable ECBC requirements. These reviews would become part of the ULB's typical approval process for construction and occupancy for the building. The third-party certificate would serve as a basis for the ULB's approval, which means the ULB would be relying on the judgment of the thirdparty inspector; the credibility of the third-party inspector would thus be crucial in this case and checks and balances are required. To guarantee the robustness of the process, ULBs need to perform scheduled and random checks on third parties' work and third parties would be penalized if violations are found.

ECBC-certified architects or third-party inspectors will review the drawings, specifications, and the Compliance Forms as given in the ECBC User Guide to ensure that the energy efficiency requirements are appropriately reflected in the project design documents or reports. If ECBC requirements are excluded or incompletely documented, the expert shall notify the design team and request additional information to ensure that ECBC requirements are met. The expert would complete and sign a letter of recommendation for approval and send the recommendation letter with the Checklist attached to the ULB or other competent authority notifying them of the findings. The ULB or equivalent entity would then issue the construction permits based on certified professional's or third party's evaluation. During the construction, third-party inspectors would be required to inspect the installation of building components and energy-efficiency technologies to make sure that the building is constructed in accordance with the design documents. If the construction does not follow the approved design, the construction contractors need to correct it or resubmit a new design for approval (if the design is changed). Upon the completion of the construction, the third-party inspector inspects the building and prepares and submits an inspection report to the ULB for approval; the ULB will issue the occupancy permit based on the recommendation of third parties.

Carefully thinking through how to involve third parties can help ensure a fair process. There should be multiple checks and certification requirements for third-party inspectors, and the government should make the final approval when third-party inspectors are used in the project. If third parties are found to be fraudulent or at fault, they need to be penalized (e.g. their licenses may be suspended or revoked, and/or they should be fined). 


\section{Conclusions}

As India continues its rapid growth and construction boom, energy consumption in buildings will increase dramatically unless strong energy efficiency policies are put in place. Building energy codes, such as ECBC, regulate building energy efficiency at the design and construction stages, and have great potential to lower Indian's building energy use and carbon footprint if well implemented through an effective enforcement system. India is just beginning to mandate ECBC implementation in a few states. Involving third parties may effectively expand the technical capacity to enforce ECBC and expedite the code's adoption and implementation.

Global experience has demonstrated that using third parties can rapidly improve compliance, when it is well organized. There are several advantages of involving third parties in compliance checks. First, it can help alleviate burdens on code officials, ULBs, and local and state governments. Second, third parties are normally professional designers or engineers, and have more expertise in technical issues and more resources through their professional affiliations. Third, using third parties for compliance checks can reduce permitting application time by allowing ULBs to distribute part of their workload to third parties. Finally, using third parties is often considered a signal to the market that the government will treat building energy efficiency more seriously, and thus helps build market awareness for building energy efficiency.

Finally, it is important to have checks and balances when using third-party inspectors. Training, certification, supervision, incentives, and penalties are essential to provide consistency and ensure objectivity for third-party programs. 


\section{References}

California Building Standards Commission (CBSC). 2010. Guide to Title 24 - California Building Standards Code. California Building Standards Commission, Sacramento, CA.

http://www.documents.dgs.ca.gov/bsc/Title 24/T24TrainingGuide.pdf , November 2012 (accessed).

Evans, M., Shui, B., \& Delgado, A. 2009. Shaping the Energy Efficiency in New Buildings -- A

Comparison of Building Energy Codes in the Asia-Pacific Region. PNNL-122267, Pacific Northwest

National Laboratory, Richland, WA.

Evans, M., Shui, B., Halverson, M., \& Delgado, A. 2010. Enforcing Building Energy Codes in China:

Progress and Comparative Lessons. Paper presented at the 2010 ACEEE Summer Study on Energy

Efficiency in Buildings: The Climate for Efficiency is Now, Pacific Grove, CA.

Fairfax County. 2012. Certified (Third Party) Inspections Program: Implementation in Fairfax County2011 Edition. http://www.fairfaxcounty.gov/dpwes/publications/thirdpartyinspections.pdf , November 2011 (accessed).

Makela, E., Meyers, J., \& Elnecave, I. 2011. Policies and Procedures for Enhancing Code Compliance. DOE Technical Assistance Program Webinar.

http://www1.eere.energy.gov/wip/solutioncenter/pdfs/Policies\%20and\%20Procedures\%20for\%20Enhanci ng\%20Code\%20Compliance.pdf, December 2012 (accessed).

Maine, 2011. FAQ about the Maine Uniform Building and Energy Code Adoption.

http://www.barharbormaine.gov/document/0001/1053.PDF, October 2012 (accessed).

Northeast Energy Efficiency Partnerships (NEEP). 2009. Effective Use of Third Party Inspectors for Enforcing the Building Energy Code.

http://neep.org/uploads/NEEPResources/id203/Third\%20Party\%20Inspection\%20White\%20Paper.pdf,

May 2011 (accessed).

Price, S. 2009. Special Plans Examiner/Inspector Enforcement Option for Washington State's NonResidential Energy Code. http://aceee.org/files/pdf/conferences/mt/2009/B4_Price.pdf , December 2012 (accessed).

Shakti Sustainable Energy Foundation. 2012. India's Work on ECBC Third-Party Assessors (Internal Discussion), New Delhi, India.

Shui, B. 2012. Third Parties in the Implementation of Building Energy Codes in China. Report No. 121, American Council for an Energy-Efficient Economy.

Smith, D.L. 2001. Alternative Code Implementation Strategies for State. U.S. Department of Energy.

Sun, X., Brown, M., Jackson, R., \& Cox, M. 2012. Making Buildings Part of the Climate Solution by Enforcing Aggressive Commercial Building Codes. Working Paper No. 71, School of Public Policy, Georgia Institute of Technology. 
U.S. Building Energy Codes Program (BECP). 2010. Building Energy Codes 101 Training Manual. http://www.energycodes.gov/becu/documents/BECU Codes 101 Training_Manual.pdf, June 2011 (accessed).

Washington State Building Code Council. 2010. 2009 Washington State Energy Code. https://fortress.wa.gov/ga/apps/sbcc/Page.aspx?nid=14, December 2011 (accessed).

Yu, S., Makela E., Evans, M., \& Mathur, J. 2012. Recommendations on Implementing the Energy

Conservation Building Code in Rajasthan, India. PNNL-21054, Pacific Northwest National Laboratory, Richland, WA. 